\title{
XIV VE XV. YÜZYIL DIVANLARINDA “KOKU” KAVRAMI ETRAFINDA OLUŞAN BENZETME VE HAYAL DÜNYALARINA BİR BAKIŞ
}

\section{THE USE OF THE "ODOR" CONCEPT IN TURKISH POETRY OF THE XIV-XV CENTURIES}

\author{
Muhittin TURAN*
}

\section{$\ddot{O} z$}

Klasik Türk şiirinde Iran ve Arap tesirinin henüz yoğun olarak hissedilmediği, şairlerin daha yerli, daha milli bir görünüm arz ettiği XIV ile XV. yüzyllarda vücuda getirilmiş divanlar incelendiğinde tabiat unsurlarının bu divanlarda çokça yer tuttuğu görülür. Bu yüzyıllar, yaklaşık altı asır sürecek olan klasik Türk şiirinde mazmun, benzetme ve hayal dünyalarının temellendirildi dönemdir. Daha çok Türkçe kelimelerle hayat bulan bu benzetme ve hayal dünyasl, çevreyi anlama ve anlamlandırma gayretinin bir ürünü olarak karşımıza çıkmaktadır. Yazımızda XIV ve XV. yüzyıllardaki divanlarda yer alan "koku" merkezli benzetme ve hayal dünyasın ortaya koymaya çalışacă̆ğ. Böylece kokunun, farkh kullanımları ortaya konulacak ve Klasik Türk şiirini daha iyi kavrama adına, onun bizlere sunduğu kültür ve sanatı anlamaya çalışacă̆ız.

\section{Anahtar Kelimeler}

Koku, Klasik Türk Şiiri, Divan, Benzetme, Hayal Dünyası.

\section{Abstract}

In the classical Turkish poetry, the influence of Iran and Arab is not felt intensely yet. When the divans which were formed during the 16th century are examined, it is seen that the elements of nature have a lot of space in these divans. This is the period in which mazmun, analogy and imagination are based on classical Turkish poetry, which will last for about six centuries. This analogy and imagination, which are mostly found in Turkish words, are the product of an effort to understand and make sense of the environment. In our article XIV and XV. we will try to reveal the world of 1 odor in centered analogy in the divans of centuries. Thus, the fragrance will be revealed with different uses and we will try to reveal the culture and art that it presents to us in order to better understand the classical Turkish poetry.

\section{Keywords}

Smell, Classical Turkish Poem, Divan, Simulation, Imagination.

\footnotetext{
* Dr. Öğr. Üyesi, Zonguldak Bülent Ecevit Üniversitesi Türk Dili ve Edebiyatı/Eski Türk Edebiyatı, muhit_33@hotmail.com, http://orcid.org/0000-0003-1499-7916
} 


\section{Gİiş̧}

Divan şairlerinin en önemli özelliklerinden biri, şiirlerini tabiattan topladıkları malzemelerle vücuda getirmeleridir. Tahayyül ettikleri tabloyu, hem bir kimyager titizliğiyle hem de malzemesi tabiat olan bir ressam estetiğiyle şekillendiren Divan şairleri iletilerini, uzun yolu tercih etmek suretiyle verirler. Bu sayede daha çok "malzeme" toparlayarak şiirlerine bir öncekinden daha fazla kültür ve estetik unsurlarını katmış olurlar ve onların "gerçek hayattan ve tabiattan kopuk" hareket etmedikleri görüşü bir kez daha ispatlanmış olur.

Divan şairleri tabiatı hemen her yönüyle şiirlerinde aksettirmiştir. Bazen bir padişah, bazen devlet veya din büyüğü, bazen de muhayyel bir sevgili olarak karşımıza çıkan memduh, bütün bir varlığın "sultanı" olarak düşünülür. Ona yakın olmanın bir ifadesi olarak da tüm tabiat şairin hizmetindedir. Soyut veya somut her türlü varlık, sevgiliye giden yolda, içerisinde çeşitli sanat unsurlarının da bulunduğu bir araçtır. Bu araçlar, hem âşığın maşuğa olan aşkını ortaya koymak için bir vesile olur hem de şairin sanat kudretini ortaya koyar. Bu araçlardan biri de koku kavramıdır. Kokunun, insanın ve bütün canlıların ana kaynağı olması sebebiyle tabiat içerisindeki konumu, Divan şairlerinin gözlem yeteneği sayesinde yine onların kalemiyle en veciz şekilde belirlenmiştir. Dolayısıyla, sınırlı şekiller içerisinde (nazım şekli, vezin, kafiye vb.) sınırsız derinlikteki tabloyu kurgulayan Divan şairinin bir kültür taşıyıcısı kimliği yüklendiği söylenebilir.

Koku bilhassa, âşığın sevgiliye yaklaşma ve ona olan ilgisini izhar etme aracı olarak kullandığı bir kavramdır. Biz bu kavramın tatbik sahasını ve bunun etrafında şekillenen diğer kavramları üç başlık altında toplayabileceğimizi düşünüyoruz.

1. Tabiat unsurları kullanılarak ortaya çıkan kokular: Rüzgâr, toprak, su vb.

2. Sevgilinin güzellik unsurlarının bizzat koku kaynağı olması: Saç, ben, dudak, ayva tüyleri vb.

3. Soyut bir kavramın etki derecesini ortaya koymak üzere onlara yüklenen anlamlar: Sevgi, korku, vefa, iyilik, aşk, cömertlik vb.

Tabiatın vazgeçilmez unsurlarından biri olan koku, şairler tarafından, bilhassa sevgilinin âşık ile olan münasebeti noktasında ele alınmaktadır. XIV ve XV. yüzyıl divanlarından ${ }^{1}$ elde ettiğimiz verilere göre bu yüzyıldaki Divan şairleri bilhassa teşhis, hüsn-i ta'lîl ve mübâlağa sanatlarını kullanarak, yukarıda üç başlık hâlinde sıralamaya çalıştığımız noktalar çerçevesinde şiirlerini kaleme almışlardır. Daha çok sevgilinin tebcili için kullanılan bir kavram olan kokuyu şairler, renk (bilhassa siyah renk), rüzgâr, cevher, şehir ve ülkeler (Yemen, Çin, Hita vb.), insanın tabiatı (yaradılışı), sevgilinin uzuvları (çene, zülüf, yüz, ben, dudak, yanak, kaş, ayva tüyleri/hat, bakış vb.), eşyaları (elbezi/mendil), tavrı, su, deniz, yazı çeşitleri, mevsimler, soyut nitelikler (vefa, cömertlik, acı, lütuf vb.), toprak, bahar, micmer (tütsü kabı) vb. ile ilişkilendirerek birçok benzetme ve hayal dünyasını ortaya koymuşlardır.

1 Söz konusu yüzyıl divanlarından taradıklarımız şunlardır: Ahmedî Dîvân, (haz. Yaşar Akdoğan), T.C. Kültür ve Turizm Bakanlığı Kütüphaneler ve Yayımlar Genel Müdürlüğü, ISBN: 978-975-17-3344-3, e-kitap; Ahmed Paşa Divanı, (haz. Ali Nihad Tarlan), Millî Eğitim Basımevi, İstanbul, 1966; Avnî (Fatih) Dîvânı, (haz. Muhammed Nur Doğan), T.C. Kültür ve Turizm Bakanlığ1 Kütüphaneler ve Yayımlar Genel Müdürlüğü, ISBN: 978-975-17-3348-1, ekitap; Cem Sultan'ın Türkçe Divanı, (haz. İ. Halil Ersoylu), TDK Yayınları, Ankara, 2013; Mesîhî Dîvânı, (haz. Mine Mengi), Atatürk Kültür, Dil ve Tarih Yüksek Kurumu, Atatürk Kültür Merkezi Yayını, Ankara, 1995; Necatî Beg Divanı, (haz. Ali Nihat Tarlan), Millî Eğitim Basımevi, İstanbul, 1963; Şeyhî Dîvânı, (haz. Halit Biltekin), T.C. Kültür ve Turizm Bakanlığı Kütüphaneler ve Yayımlar Genel Müdürlügü, ISBN: 978-975-17-4078-6, e-kitap; Ahmed-i Dấ̂ Divanı (Metin-Gramer-Tıpkı Basım), C I, (haz. Mehmet Özmen), TDK Yayınları, Ankara, 2001. 
Koku, başta tabiat unsurları olmak üzere çeşitli varlıklara benzetmelik olmasının yanında şifa ve can vermesi, âşı̆̆ı kendinden geçirmesi, hayatın anlamı olması gibi özelliklere de sahiptir.

Divan şairlerince daha çok maharet göstermek amacıyla ele alınan tabiat unsurları ve özelde koku kavramının, Bahâriyye, Bahâriyyât veya Nevrûziyye başlıklı nazım türleri altında baharın neşesi, tabiatın yeniden doğuşu gibi konular işlenirken çokça ele alınan kavramlar arasında olduğunu ve tabiat tasvirlerinin oldukça yoğun bir şekilde işlendiği bu edebi türlerin "özellikle Divan şiirinin ilk dönemlerinde daha yoğun olarak kullanıldığını" (Gökalp, 2011: 298) ekleyelim.

Koku kavramı etrafında, söz konusu yüzyıllarda vücuda getirilen divanlarındaki benzetme ve hayal dünyası incelendiğinde, bu kavramı karşılayabilecek olan kelimelerin üç grupta toplandığını söyleyebiliriz. Misk² (müşg), reyhân ${ }^{3}$ (reyâhîn), amber ${ }^{4}$, abîrir ${ }^{5}$ 1tr' (attâr), kâfûr ${ }^{7}$, nâfe ${ }^{8}$, gâliye ${ }^{9}$ gibi kendisi bizzat güzel kokulu bir madde olanlar; bûyâ ${ }^{10}$, tîb ${ }^{11}$ gibi herhangi bir güzel koku sürüldügünde güzel kokanlar, yani sıfat olarak kullanılanlar ve râyiha, bûy, nekhet ${ }^{12}$, şemîm, şemm (şemme) ve fâyiha ${ }^{13}$ gibi tanımında "koku" veya "güzel koku" olanlar.

$\mathrm{Bu}$ benzetme ve hayal dünyasında koku kavramı çok çeşitli şekillerde karşımıza çıkmaktadır: Koku, Çin, Hıta (Hoten) ile birlikte ele alınır, hatta bunlardan daha üstündür. Misk kokulu hat (ayva tüyleri, güzelliği), sevgilinin mushafa benzeyen cemalini tefsir eder. Sevgilinin kapısının eşiği misk kokar. Misk, zülfün bulunduğu yeri utancından terkeder. Sevgilinin güzel kokulu ayva tüyleri yani hattı, tevriyeli kullanılarak genellikle Gubârî ve Reyhânî yazı ile ilişkilendirilir. Sevgili, ayağının tozu/toprağını eteğinden etrafa saçtığından dolayı Çin miskine rağbet kalmamıştır. Sabah rüzgârı, sevgilinin bağını, bahçesini yine zülfünün kokusuyla süsler. Zülüf bazen misk kokulu bir başak oluverir. Hita (Hoten) miskinin bağrı, sevgilinin zülfü karşısında kan içinde kalır. Zülüf, misk kokulu bir zincirdir ve bununla âşığın/âşıkların gönlünü asar. Seher rüzgârı sevgilinin sümbüle benzeyen saçını çözdüğü için âşığın gönlüne de attârın nefesi gelmiş olur. Zülüf, etkileyici kokusu ile âşığın aklını başından alır, onu mecnun

2 Bir cins ceylanın göbeğinden çıkan güzel kokulu bir madde ki en meşhûr ıtriyâttandır (Kâmûs-ı Türk̂̂, 1317: 1343). Hatâ gazellerinin göbeğidir. Arabîde misk denir (Burhân-ı Katı, 2000: 524). "Müşk dedikleri meşhur nesne. Farisiden mu'arrebdir (Ahterî-i Kebir, 2009: 661). Ç̂̂n vilâyetinün geyiklerinin göbegidür. Eydürler ki ol geyikler za'ferân otlarlar (Lügat-i Ni'met'ullâh, 2015: 4 69).

3 Fesleğen denilen güzel kokulu nebât (Kâmûs-ı Türk̂̂, 1317: 677). Reyhân, aynı zamanda diğer güzel kokulu maddelerin genel adı da olmuştur (Ahterî-i Kebir, 2009: 810).

4 Ada balığının midesinden çıkardığı güzel râyihalı siyâh bir mâdde ki bahr-i Hind sevâhilinde ba'zı sı ̆̆ mahallerinde bulunur (Kâmûs-ı Türkî, 1317: 953). Aynı zamanda deniz içinde bir ağacın zamkıdır (Ahterî-i Kebir, 2009: 47). Başka bir kaynağa göre ise Kaşalot denilen balığın, midesinde hazmedemediği maddelerden elde edilir ve diğer kokulu maddelerin genel adıdır (Mükemmel Osmanlı Lügati, 2009: 12).

5 Bir ilaç terkibi. Bu terkip, beyaz sandal, sümbül kökü, kırmızı gül, turunç ve iğde çiçekleri, narenç gibi güzel kokulu bazı otlarla bir miktar dövülmüş miskten meydana gelirmiş (Devellioğlu, 1990: 5). Bazı kaynaklar amberin eş anlamlısı olduğunu söyler (Kâmûs-ı Türk̂̀, 1317: 927; Resimli Türkçe Kamus, 2004: 1). Za'ferân için de kullanılır (Ahterî-i Kebir, 2009: 26).

6 Güzel kokulu yağ... Yapraklarının kenârları tırtıllı, yeşil renkte bir nebât ki güzel kokulu ve beyâz çiçekli olup bahçelerde bulunur ve soğuğa dayanmadığından kışın limonluğa alınır (Kâmûs-ı Türkî, 1317: 940).

7 Hindistân cihetlerinde defneye müşâbih bir küçük ağacın zamkından ibâret olan pek beyâz ve güzel, sert kokulu bir mâdde-i tayyibe, câmid bir yağ (Kâmûs-ı Türkî, 1317: 1139).

8 Misk âhûsu denilen hayvanın göbeğinden çıkarılan bir çeşit misk, koku (Devellioğlu, 1990: 952). Âhûnun misk içeren kesesine verilen ad (Kâmûs-ı Türkî, 1317: 1449).

9 Misk ve anberden mürekkep güzel kokulu siyâh bir ma'cûn ki saça ve kaşa sürülür (Kâmûs-ı Türkî, 1317: 961).

10 Ziyâde kokulu nesne (Lügat-i Ni'met'ullâh, 2015: 93; Burhân-ı Katı, 2000: 104).

11 Hoş kokulu nesne (Ahterî-i Kebir, 2009: 1026).

12 Aslı "nekhet" olan bu kelimenin taradığımız divanlarda "nükhet" şekli tercih edilmiştir.

13 Güzel koku (Kâmûs-ı Türkî, 1317: 980). Ayrıca "koku” kavramının eş anlamlıları için bk. Lehcetü’l-Lügat, Şeyhülislam Mehmed Esad Efendi, (haz. Ahmet Kırkkılıç), TDK Yayınları, Ankara, 1999, s. 437. 
yapar. Sevgilinin ayağının, mahallesinin tozu bir misk olarak görülür. Zülüf, iki kanadı da misk ve amber olan bir tavus kuşu olur. Âşık, gülsuyu ve misk ile ağzını defalarca yıkasa da sevgilinin yanak ve zülfünü anma cüretini gösteremez. Onun kokusunu taşıyan sabah rüzgârı, ûd, misk ve amberi etkileyiciliğiyle mat eder. Zülüf, gece renkli, misk kokulu bir "yokluk şehri" olur. Her türlü varlığın "dimağ"ı sevgili sayesinde dünyanın en güzel kokularıyla dolar. Sevgilinin can bahşeden dudağ gibi tatlı dili de misk gibi kokarak her derde derman olur. Kara zülüfteki misk kokusu, Çin'deki ahunun karnında dahi bulunmaz. Dolayısıyla misk, zülüf gibi etkileyici kokamaz. Zülüf, cirit oynanan misk kokulu sopa olur. Hita, sevgilinin kokusunu taşıması sebebiyle sabah rüzgârıyla boy ölçüşemez. Kaş, misk kokan bir gölgelik olur. Kalem, sevgilinin misk gibi kokan ayvacık tüylerini, yani güzelliğini yazmaya muktedir değildir. Kaş, amber kokulu nun harfi veya hilâldir. Sevgilinin misk kokulu "ben"i âşığın gönülde yer alan siyah bir aşk tohumu olur vb.

İncelediğimiz XIV ve XV. yy. divanlarında koku ile ilgili rastladığımız kelime ve tamlamalardan bazılarını şu şekilde verebiliriz:

Müssg-i gûuâ, müşg-i nâb, müşgîn, müşg, meşâmm, müşg-i Çîn, müşg-bû, müş̧g-bâr, zülf-i müşgîn, müşg ü anber, nesîm-i müşg-bâr, misk-efşân, hatt-ı miskinn, misk-i ter, misk-i Hıta, misk-i Hoten, âh $\hat{u}-y \imath$

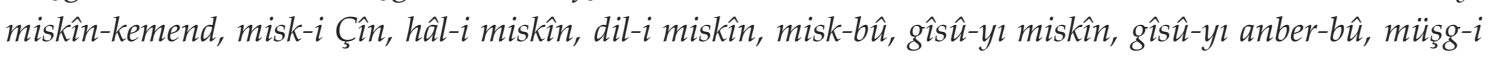
ter, hâşe-i müşgîn-'ineb, kâkül-i müşgîn-i dost, gubâr-ı müşg, ter müşg, müşg-i Tatar, müşg-i Hıta, müşg-dem, müşg-efşân, müşg-fâm, nâme-i müşgîn, seccâde-i müşgîn, berg-i müşg-âgîn, meftûl-i müşgbâr, zülf-i müşg-bâr, zülf-i müşg-bûy, hat-ı müşg-bâr, ebr-i müşgîn-i gül-âb-efşân, müşgîn-i gonca, turra-i müşgîn, turra-i anber-feşân, silsile-i müşg-i ter, müşgîn-nefes, müşg-rîz, zencîr-i müşg, ebr-i müşg-efşân, hatt-ı reyhân, reyhân-ı cennet, kâkül-i reyhân, nâfe-i Tatar, mûy-i nâfe, nâfe-i hulk, nâfe-i

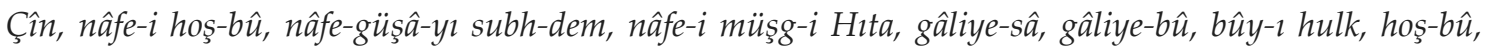
bûy-ı vefâ, bûy-ı zülf, anber-âmîz, bûy-i misk, şemme-i bûy, nihân-ı müşg, bûy-ı anber, bûy-ı cân, bûy-ı gül, bûy-ı zenehdân, bûy-ı Yûsuf, zülf-i anber-efşân, zülf-i anber-sâ, zülf-i anber-fâm, na'l-i anber, şemme-i zülf, şemme-i lutf, şemme-i elem, miyân-ı müşg, meşmûme-i anber-şemîm, attâr-i sabâ, külbe-i attâr, gül-âb-ı attâr, ca'd-ı müşg-bâr, ıtr-güş̧â, kâfûr-ı ter, şem'-i kâfûrî, zülf-i siyeh, zülf-i semen-bû, nâv-dân-ı müşg, zülf-i misk-âsâ, dâm-ı anber, habb-ı miskîn, duhân-ı müşg, zülf-i miskîn, müşgîn-hat, mü̈sîn-hevâ, müşg-feşân, müşg-sâ, hatt-ı muanber, dil-i miskinn-i perî̧̧ân, hâl-i muanber, hâl-i anberbâr, zülf-i anber-bû, bûy-i mey-i la'l, hevâa-yı zülf-i müşgîn, bûy-i nigâr, bûy-i nâfe-i Tatar, bûy-i zülf-i anber-bâr, bûy-ı gül, nükhet-i pîrâhen, nükhet-i hulk, çevghân-ı müşg, nokta-i anber, bahr-ı müşg, mey-i müşg-bûy, müşg-peyker, ebrû-yı müşgîn, râygân-ı müşg, âşiyân-ı müşg, müşg-i her-câŷt, müşg-bîz, anberîn-nefehât, anberîn-selâsil, anber-i hâm, anber-i ter, anber-bûy, çetr-i anber, anber-i sârâ, dâne-i anber, hilâl-i anberîn, nişân-ı müşg, turre-i anber-nisâr, nokta-i anber, bûy-i râhat, zülf-i anber-bâr, hâl-i müşgin-dâne, anberîn, bûy-ı "lâ", bûy-ı latîf, anber-çinn, sâyebân-ı müşg, rîsmân-ı müşg, savlecân-ı müşg, gâliye-i turre-i anber-sâ vb.

Umumiyet itibariyle koku ile ilgili benzetmeler şu şekildedir:

Aşağıda Ahmedî'nin "kılıç" ile "kalem"in muhaveresini anlattığı manzumesinden alınan beyitte, kalemin mürekkebi misk kokulu bir denize benzetilmiştir.

Pes ḳılıç didi ki sīm ü zerdurur baña makām

Pes ḳalem didi ki baḥr-1 müssgdür baña diyār (Ahmedî, K. 25/13, s. 70) ${ }^{14}$

14 *Parantez içindeki “K." kasideye, “G." de gazele işaret etmektedir.

* Beyitlerin sonunda bulunan şiir, beyit ve sayfa numaraları, divanların kaynakçada verilen baskılarına aittir. 
Sabah rüzgârı, sevgilinin diyarından, Hz. İsa'nın nefesi gibi ölüleri dirilten bir koku getirir.

İy șabā cānuñ içün yār diyārından irür

Şol hevāyı ki öli diri ḳılandur ḳohusıs (Şeyhî, G. 192/5, s. 157)

Hz. Yûsuf'un kokusu nasıl Hz. Yakup'un gözünü açıp onu ihya ettiyse, sevgilinin gömleği de âşığa o derece can verir. ${ }^{15}$

Būy-i Yūsuf dìde-i Yacḳūba verdi ise bașar

Aḥmed'e cān virdi yāruñ nükhet-i pỉrāheni (Ahmed Paşa, G. 347/7, s. 349)

Aşağıdaki beyitte ise Hz. Yûsuf'un Mısır'daki köle pazarında, içerisinde miskin de bulunduğu ağırlığınca altın, gümüş ve değerli kumaş ile Mısır Azizi'ne satıldığı bilgisi yer almaktadır.

Şatılduğında Yūsuf dartıldı gerçi miske

Sen cāna dartılursın aylakssın ol bahāya (Ahmed Paşa, G. 263/8, s. 293)

Hz. Yûsuf'un misk ile tartıldığı hadisesine telmihte bulunularak, cihan sarrafı olan Necâtî'nin inciye benzeyen söze değer kattığı ifade edilir.

Söz Yūsufinı müssg ile țartardı Necātī

Kııymet ḳosa ṣarrāf-ı cihān bu güher üzre (Necâtî, G. 479/7, s. 438)

Kokunun yukarıda belirtmeye çalıştığımız genel kullanımlarından sonra, aşağıda başlıklandırılan kavramlarla ilişkileri şu şekilde verilebilir.

\section{Ayva Tüyleri}

Ayva tüyleri, siyahlığı ve ufalanmış miski andırması münasebetiyle koku ile birlikte kullanılır. En çok amber ve misk ile anılır. Aşağıdaki beyitte zülüf bir pusu, amber kokulu ayva tüyleri de gönül avlamak için bu pusuda bekleyen bir asker olarak tasavvur edilmiştir.

Zülfüñ altına siñüb hatț-ı mu'anber gizlenür

Șan ki dil almag içün pușıda leşker gizlenür (Necâtî, G. 124/1, s. 221)

Divan şiirinde yanak, suya ve ateşe benzetilir. Misk ve amber kokulu olan ayva tüyleri, tütsü için bu ateşte yanan güzel kokulu maddelerdir (Erdoğan, 2013: 219). Sevgilinin yanağındaki misk kokulu hatlar, yine misk kokulu bir duman şeklinde ortaya çıkar.

‘Āriż u ruhsār içinde hattel-1 canber-bār-1 dost

Dūd-1 müşg-āsādürür kim āb u āteşden çıḳar (Necâtî, G. 197/3, s. 267)

*** Örneklerde, beyitlerin alındığı divanların imlasına sadık kalınmıştır.

15 Bu konu, Kur'ân-1 Kerîm'de şu şekilde geçmektedir: "Kervan (Mısır'dan) ayrılınca babaları, "Bana bunak demezseniz, şüphesiz ben Yûsuf'un kokusunu alıyorum" dedi... Müjdeci gelip gömleği Yakup'un yüzüne koyunca gözleri açılıverdi." Yûsuf Suresi/94, 96. 
Şehir ve ülke adları Divan şiirinde çok anlamlılık ilişkisi içerisinde kullanılabilir. Örneğin Çin ülkesi "putperestlik, ahu, misk" kavramlarını çağrıştıracak şekilde yer tutabilir. Bununla birlikte Aydın, Tire ve Germiyan da koku kavramı çerçevesinde mütalaa edilebilir. Aydınoğullarının bir dönem payitahtı olan Tire, Farsça "tîre" kelimesiyle ilintilendirilerek "bulanık, karanlık" anlamlarında kullanılır (Arıkoğlu, 2008: 139) ve "ben"e benzetilir. Aşağıdaki beyitte sevgilinin yanağ 1 Germiyan, misk kokulu ayva tüyleri/güzelliği de Karesi'dir.

Aydın içinde Tîredürü̈r hāall-i cāriżuñ

Ruhsār Germiyan haț-1 müsggindür (Karesi) (Necâtî, G. 171/6, s. 251)

Aşağıdaki beyitte sevgilinin misk yüklü ayvacık tüyleriyle dolu dudağı, büyülü bir şeker gibidir. Bu şekilde, ayva tüylerinin hem koku hem de tat duyusu ile ilgisi ortaya konur.

Gel ki hattt-1 müşg-bāruñla lebüñ

Beñzedi efsūn oḳunmış sükkere (Necâtî, G. 526/3, s. 470)

Sevgilinin şaraba benzeyen dudağının üstündeki ayva tüyleri, güzel kokusuyla fitne koparir.

Görineli haț-1 müssgini lac-i nāb üzre

Ne fitneler belüri başladı şarāb üzre (Necâtî, G. 523/1, s. 468)

Güzellerin olduğu yerde güzel kokuların olması nasıl tabii ise sevgilinin yanağında misk kokulu ayva tüylerinin varlığı da o kadar tabiidir.

Hatț-1 miskỉn olsa haddinde nigāruñ tañ degül

Çün nigāristānda olmaz hatṭt-1 canber-sā garỉb (Ahmed Paşa, G. 12/5, s. 131)

\section{Bahar}

Koku ve renk bir arada kullanılarak, âşığın rengi "sonbahar"a, sevgilinin kokusu ise "ilkbahar"a benzetilmiştir.

Nice ki reng-i āşılk u būy-i nigārdan

Görine yir yüzinde hazān ile nev-bahār (Ahmed Paşa, K. 34/34, s. 96)

\section{Ben (Hâl خال)}

Kokunun kullanıldığı yerlerden biri de "ben"dir. Daha çok siyah renk ${ }^{16}$ münasebetiyle ele alınır. Ayrıca satrançtaki piyon (beydak) taşına benzetilir. "Miskîn" kelimesi tevriyeli kullanılarak, âşığın gönlü zavallı (miskin) bir kuş olur ve sevgilinin "ben"inin sevdası için zülfünün tuzağına düşer.

Hāli sevdāsinda göñlüm düssdi zülfi bendine

Murǵ̀-1 miskinndür düsser dāne görüb dām üstine (Ahmed Paşa, G. 277/5, s. 302)

16 İncelediğimiz divanların sadece birinde ve bir beyitte ben (hâl), yeşil renk olarak tahayyül edilmiştir:

Yeşil beñler yaraşur ḳaşlaruñda

Ki sādāt oturur mịhrāb içinde (Necâtî, G. 540/2, s. 480) 
Sevgilinin ateş kırmızılığındaki dudağının üstünde var olan güzel kokulu "ben"ler, yakuttan yapılmış, tütsü yakılan kap içindeki misk ve amber gibidir.

Āteş-i laqü̈ñde ol hăàl-i mucanber fi' 'l-mesel

Mecmer-i yākūt içinde müssg ile canber düter (Ahmed-i Dâ'î, G. 38/2, s. 85)

Beyitlerde genellikle piyâde olarak karşımıza çıkan beydak, satrançta en değersiz taştır. Siyah rengi ve küçüklüğünden dolayı sevgilinin yanağındaki benler, bu taşa benzetilir (KaplanPoyraz, 2010: 153). Ayrıca ruh (yanak) da kale taşına benzetilir. Piyona benzetilen ben (hâl), askerlerini sevgilinin yanağı (kalesi) üzerine sürer.

Sürdüñ ruh-i yār üzre beydakın ey ḩāl

Murğ-1 dil-i miskine eger dāne degülseñ (Necâtî, G. 293/4, s. 324)

Hızır nasıl âb-ı hayatın, yani ölümsüzlük suyunun başında ise, sevgilinin misk kokulu "ben"i de bir ölümsüzlük suyu olan dudağında bekler. Dolayısıyla ben, Hızır olarak tasavvur edilir.

Hāl-i müşgin dudag்uñda nice konmışdur didüm

Didi Hiżruñ yiri olur çeşme-i āb-ı hayāt (Ahmedî, G. 93/3, s. 264)

Aşağıdaki beyitte ben, rengi münasebetiyle kokulu bir sineğe benzetilmiştir.

Şol leblerüñdeki meges-i anberin midür

Yā țŭtị mi ki buld şeker-h̆āne beñlerüñ (Şeyhî, G. 103/3, s. 115)

"Hâl خال kelimelerinin ses benzerliğinden faydalanarak, sevgilinin "ben"inin etkileyici kokusunun âşıkları zor duruma soktuğu belirtilir.

Gül yüzde müssin hālüñi göreli miskin göñlüme

Bir ḥāl-i müşkil düşsdi kim kimse bu hạāe düssmesün (Ahmedî, G. 513/5, s. 512)

Aşağıdaki beyitte hem zülfün hem de "ben"in koku özelliği merkeze alınmıştır. Zülüf, sabah rüzgârının kendisini daha da kıvrımlı hâle getirmesiyle, sanki bir tornavida gibi, sevgilinin gül yanağı üzerindeki amber (nokta-i anber) kokulu "ben" $i$ perçinlemektedir. Dolayısıyla "ben" in güzel kokulu olma özelliğini daha da artırmaktadır.

Çün șabā ol zülf-i müşgin țurrasın çin eyledi

Noḳta-i anber ile gül üzre perçin eyledi (Şeyhî, G. 201/1, s. 161)

Sevgilinin "ben"i, tevriyeli kullanımla "miskîn"e hem güzel koku hem de zavallı, aciz anlamları verilmiştir. Ayrıca "dâne" kelimesi de böyledir. Hem adet hem de tohum anlamları düşündürülecek şekilde kullanılmıştır. Fakat sonuçta onun zavallı ve aciz değil, fitne ve karışıklık çıkarmada bir tane/dâne olduğu hükmüne varılır. 
Hālini miskỉn șanursız fitnede bir dānedür

Ṣaçları dām-ı belādur bilmez anı bilmeyen (Necâtî, G. 418/4, s. 399)

\section{Cevher, İnci}

Güzel koku ile cevher ve inci arasındaki ilişki genel itibariyle bulutun sevgilinin saçına teşbih edilmesi ve bu buluttan misk kokulu inci gibi damlaların yağması; Hindistan'da inci ve diğer mücevheratın çıkarılmasının yanında, Hindistan'ın "siyah" rengi ve dolaylı yoldan sevgilinin "ben"ini hatırlatması; edebiyatımızda en güzel ve değerli incilerin kaynağı olan (Yeniterzi, 2010: 304) Aden şehrinin incileri ile güzel koku arasında bağlantı kurulması münasebetiyle ele alınır. Aşağıdaki beyitler bu durumu örnekler niteliktedir.

Sevgilinin saçına benzetilen bulut, müşg ve amber kokusu yağdırmaktadır.

Hevādan șaçılalı müşg ü canber

Bulttan dökilür uş dürlü güher (Ahmedî, K. 38/1, s. 100)

Sevgilinin sözleri güzel kokulu bir inci olur.

Vașf ider Aḥmedī lebüni anuñçun

Sözleri anuñ ną̧m-ı laq ü dürr-i şemímdür (Ahmedî, G. 208/7, s. 350)

Sevgilinin zülfü ile Aden şehrindeki incilerin kokusunun aynı olduğundan bahsedilir.

Dāciol zülf-i mucanber ḳoḳusın şerḥ ideli

Tỉb-i enfāsını gör tịib-i ‘Adendür kokusı (Ahmed-i Dâ'̂̂, 180/7, s. 178)

\section{5. Çene}

Özellikleri münasebetiyle farklı şekillerde ele alınan ve daha çok zenehdân, enek ve zekan kavramlarıyla anlatılan sevgilinin çenesi, şaire göre bir elmadır ve bu elmanın etrafa yaydığı koku bir burunun koklayacağı en güzel kokudur.

Bir turunc itdi tekellüf bize ol sỉb-zekān

Ki meşāmı ter ider būy-ı zenehdānı gibi (Ahmed Paşa, G. 314/4, s. 326)

Sabah rüzgârı, sevgilinin nara benzetilen yanağını ve elmaya benzetilen çenesini koklar.

Yanag̉uñ nārını eyvāy niçün bād-1 șabā

Koḳular anuñ içün sỉb-i żekandur ḳoḳusı (Ahmed-i Dâ'î, 180/5, s. 178)

\section{Dudak}

Dudağın koku ile olan münasebeti, genellikle gonca ile olan ilgilisiyledir. Goncanın tam ortasındaki siyah nokta ile miskin siyahlığı arasında ilgi kurulur. Gonca, misk taneleri ile ağzını doldursa da sevgilinin şeker yüklü dudakları kadar olamaz.

Habb-ı misk ile dehānın pür ide gonca velī

Luṭ ile öykinimez lac-i şeker-bārlara (Necâtî, G. 463/4, s. 427) 
A $\dot{g}$ Zınuñ rāyiḥası içün götürür habbü'l-misk

Gonca hịç öyküne mi lacl-i şeker-bārlara (Necâtî, G. 465/4, s. 429)

\section{Kaş}

Kaş-koku münasebeti bilhassa siyah renk itibariyle ele alınır. Dolayısıyla kaş daha çok misk ile anılır. Sevgilinin kaşı ya mihrabın kıvrımı ya bayram hilali ya da misk kokulu gümüş kabzalı bir keman olur.

Bu kaş mı yā ham-1 mị̣rāb yā hilāl-i cìd

Yā müş̧g tozlu gümüş ḳabżalu kemān ola mı (Ahmed Paşa, G. 324/2, s. 333)

Aşağıdaki beyitte kaş, güzel kokulu bir gölgelik ve amber kokulu zülüf de o gölgeliğin çadır ipi olmuştur.

Kaşuñla zülfüñi gören aydur ne yaraşur

Bu müssg sāye-bān ile ol canberīn tınāb (Necâtî, K. 3/39, s. 29)

Aşağıdaki beyitte misk kokulu kaş, hilale benzetilir.

Bedr ü hilāli bir arada göreyim diyen

Uş māh yüzde ebrū-yı müssgin hilāl-i dost (Ahmedî, G. 83/4, s. 259)

Sevgilinin kaşları, iki misk kokulu keman gibidir.

Hüsnüñ ki mesken eyledi ḩaddüñ serīini

Ṣundı kạ̧uñ revān aña miskīn iki kemān (Avnî, G. 60/2, s. 27)

\section{Rüzgâr}

Divan şiirinde sık kullanılan rüzgâr çeşitlerinden biri olan bâd-1 sabâ, daha çok taşıma, dağıtma ve yayma münasebetiyle ele alınır. Sabah rüzgârı, güzel kokusu sebebiyle sevgilinin saçlarına düşkündür. Onu çözer, dağıtır, uçurur. Sevgilinin saçlarına dakunduğu için güzel kokar. Sabânın taşıyıp dağıttığı kokuların başında misk, amber, sümbül ve reyhan gelir (Batislam, 2005: 98).

Sevgilinin zülfünün kokusunu taşıyan ve bir ulak vazifesi gören sabah rüzgârının nefesi tabii olarak misk gibi kokacaktır.

Yine sevdāyĩ göñül bir zülfe itmişdür heves

Kim hevāsından olur bād-1 șabā müşginin-nefes (Ahmed Paşa, G. 127/1, s. 203)

Aşağıdaki beyitte sabah rüzgârı attâra benzetilmiştir.

Zülfi ḩaberin bād-1 șabādan ne șorarsın

Bir misk adını bilmege catțār gerekmez (Necâtî, G. 213/2, s. 277) 
Aşağıdaki beyitte bir ıtır satıcısı, yani attâr olan sabah rüzgârı (attâr-1 sabâ), bir misk ve abîr olan sevgilinin ayak tozunu, çok değerli olduğu için, dirhem dirhem satar.

İzüñ tozın șabā yili șatar direm direm

Misk ü abìir ḳadrini cattār yeg bilür (Necâtî, G. 204/4, s. 272)

Âşık, ettiği “âh” tan sevgilinin kaçınmasını ister, yani sevgilinin zülfünün kokusu karşısında âşık da onu "âh" ile tehdit eder.

Āhından Aḥmed'üñ șakın ey dost zülfüñi

Bu müşsg-i nābı bād alur itmezseñ ịhtirāz (Ahmed Paşa, G. 118/5, s. 198)

Şair, dervişler ile sabah rüzgârı arasındaki mukayesede "miskîn" kavramını tevriyeli olarak kullanır. Sabah rüzgârının bir yol eri, yani sevgili uğrunda her türlü engel ve acıya göğüs geren biri olduğundan ve tam bir teslimiyet içinde sevgilinin misk kokulu zülfüne can verdiğinden bahsedilir.

Yol eridür yüzi yirde zülf-i yāra cān virür

Gel ṣabādan ögrenüñ dervişler miskỉnlügi (Necâtî, G. 623/2, s. 538)

\section{Saç/Zülüf}

Koku kavramının en çok kullanıldığı yer sevgilinin zülfüdür ${ }^{17}$. Misk (müşg), bûy, ahu, nâfe, kan, Tâtâr, Hatâ /Hıtâ gibi unsurlarla zengin bir tasavvur alanı oluşturulur. Çîn kelimesinin "kıvrım, büklüm" gibi anlamlarıyla sevgilinin misk kokulu saçları (zülüf, turra), bazen de kaşları (ebrû) ile ilgi kurulur (Yeniterzi, 2010: 310). Sevgilinin kokusu, bazen yukarıda sayılan ve kokusuyla meşhur olmuş nesne ve şehirlerle aynı seviyede tutulur. Çoğu kez de sevgilinin bunlardan daha üstün bir kokusunun olduğunun altı çizilir. Ayrıca saç, reyhan, şebboy (şebbû), yasemen, sümbül, menekşe gibi güzel kokulu bitkilerle birlikte anılır.

Saç/zülüf ve koku merkezli oluşan benzetme ve hayal dünyasından bazıları şunlardır: Zülüf, amber tuzağı, ben ise misk tanesidir. Tevriyeli bir kullanımla sevgilinin saçlarının kıvrımları, gönülleri miskin eder. Zülüf, misk kokulu bir çevgan olur. Misk ile gül, zülfün kokusunun yanında baş ağrıtıcı kokulardır. Misk, sevgilinin saçından utanır. Cennette bile sevgilinin saçı kadar güzel bir koku yoktur. Sevgilinin saçı Hıta'ya armağan olarak gider. Akıl, güzel kokulu saçtan inler, perişan olur ve misk gibi kokar. Sabah rüzgârı, sevgilinin sümbüle benzeyen saçını dağıtır ve bu durum "reyhan vaktinin gelmesi" olarak değerlendirilir. Sevgilinin menekşe kokulu zülfüne amber bile köle olur. "Saçın yüzün iki tarafında, yanakların üzerinden çeneye doğru sarkık ve ucu eğri hâli bir beyitte amber kokulu çevgana benzetilmektedir. Çevgan, top oyununda kullanılan ucu eğri bir sopadır. Daima gûy (top) ile birlikte kullanılır. Güzelin saçı çevgan olunca, çene de top şeklinde hayal edilir" (Öztoprak, 2004: 323).

Sümbüle benzeyen sevgilinin saçının kokusu, misk gibi kokan otlar bitirir. Kokunun aslında kaynağı olan ahu, o etkileyici kokusunu sevgilinin saçından alır. Dolayısıyla başka kaynağa ait olan bir özellik, sevgiliye atfedilir.

17 Sevgilinin saç kokusu bağlamında kullanılan kavramların XIV ve XV. yüzyıl divanlarındaki kullanım sıklığı hakkında bk. Muhammet Ali Demir (2015), Divan Şiirinde Sevgilinin Saçının Kokusu, basılmamış yüksek lisans tezi, Boğaziçi Üniversitesi, s. 80-82. 
Toprağa sevgilinin zülfünden bir esinti gelse, bu durum yerin altındaki çürümüş kemiklere can kokusu getirir. Dolayısıyla zülfün kokusu hayat vermektedir.

Hāke zülfü̈ñden irişürse nesim

Cān kohususin bula izāām-ı remīm (Ahmed Paşa, G. 188/1, s. 243)

Sevgilinin zülfünün sevdasıyla can veren âşığın toprağı amber, kemikleri de misk kokar.

Sevdā-yı zülf-i yārıla ger cān virürse Cem

Cismi türābı canber olur üstüh ānı müssg (Cem, G. 183/14, s. 146)

Sevgilinin menekşeye benzeyen zülfünün kokusunun hayat vermesi ile Hz. İsa'nın ölülere ve cansız varlıklara can vermesi ${ }^{18}$ birlikte anılır. Hangisinin daha üstün olduğu sorgulanır.

Nefḥa-i canber mi yā zülf-i benefşe cān viren

Yã dem-i đIssi bigi bād-ı mucatțar devridür (Şeyhî, G. 34/2, s. 83)

Misk bile sevgilinin "külbe-i attâr"19 yani koku dükkânı olan ve sümbüle benzeyen saçından istifade etmek ister.

Sünbülü̈ñden șanemā şsemme-i būy almak içün

Misk sevdāya düşüb külbe-i cațtāra gider (Ahmed Paşa, G. 77/3, s. 173)

Saç, nura benzeyen yanağın üstündeki amber çadırdır.

Mukayyed itdi ser-ā-ser cihānı bir ḳılıla

Șaçuñ sevādı ki nūr üzre çetr-i canber olur (Ahmedî, G. 198/5, s. 342)

Bütün dünya sevgilinin güzellik askerleriyle dolmuş olup saçı da güzellik şâhına, yani yanağına kurulmuş misk kokulu bir gölgelik olur.

Pür oldı hayl-i hüsnüiñ ile yine bu cihān

Hüsnüñ şehine kurdı șaçuñ müşsk sāye-bān (Avnî, G. 60/1, s. 27)

Sevgilinin gece renkli saçı, misk kokulu bir perdeye benzetilir.

Cihān cemāli bu müşgīn tutuḳdan oldı cayān

Șanasın açdı ruh-i dost țurra-i şeb-reng (Ahmed Paşa, K. 22/3, s. 63)

Divan şiirinde sevgilinin saçı veya "ben"leri ile çoğu kez siyah renkle birlikte misk/müşg, nâfe, bağır, ciğer, hûn, ahu, gazâl, Çîn, Tâtâr ve Türk-i Hatâ gibi unsurlarla bir arada kullanılır (Yeniterzi, 2010: 313). Aynı şekilde, kokunun söz konusu edildiği yerlerde Moğol ve Tibet de anılır. Ayrıca saç ile diğer kokular arasında kurulan teşbih münasebeti daha çok mukayese mahiyetinde olmaktadır (Tolasa, 2001: 161).

18 Bu bilgi Kur'ân'da şu şekilde geçmektedir: “...Ben çamurdan kuş şeklinde bir şey yapar, ona üflerim. O da Allah’ın izniyle hemen kuş oluverir..." Kur'ân-1 Kerîm, Âl-i İmrân Suresi/49.

19 "Külbe-i attâr" tamlaması sevgilinin saçından kinayedir (Pala, 2010: 41-42). 
Aşağıdaki beyitte sevgilinin "ben"i Rum memleketlerini haraca bağlamakta ve saçı da Hoten miskinden ve Çin'den haraç ve vergi almaktadır.

Ey hāal-i ruhuñ memleket-i Rūm harāà

Cā̄iz ki șaçuñ misk-i Hutenden ala bācı (Necâtî, G. 566/1, s. 498)

Şaçuñ koḳusı müssg-i Hițadur

Alur harāầı Çinden efendi (Ahmed-i Dâ'̂̂, G. 188/3, s. 183)

Aşağıdaki beyitte, miskin kandan oluştuğu bilgisi hatırlatılarak, sevgilinin zülfünün miske kan yutturduğu, ${ }^{20}$ yani miskin sevgilinin zülfünün kokusu karşısında çok aciz kaldığı anlatılır.

Bir gice sevdā-yı būy-ı zülf-i yār itsem gerek

Misk gibi kan yudub terk-i diyār itsem gerek (Ahmed Paşa, G. 152/1, s. 219)

Amberin ada balığının karnından, dolayısıyla denizden çıkarılması hadisesi hatırlatılır. Amber, sevgilinin misk kokulu saçına özenirse, yüzünü yedi denizin suyu ile yıkasa da bu yüz karasını gideremez.

Miskin saçuna öyküneli anber ey șanem

Yumaz yidi deñizler ile yüzi ḳarası (Necâtî, G. 611/3, s. 529)

Sevgilinin saçlarının kokusunun etkileyiciliği, yakıldığında etrafa güzel kokular yayan ûd (öd) ağacı ve Hita müşgü ile eş değerde tutulur.

\section{Zülfü̃ñ kohusıyıla mucattardurur hevā}

Bu 'ūd mı ya canber ü müssg-i Hıtā mıdur (Ahmedî, G. 183/2, s. 330)

Tatar illerinin güzel koku ile olan münasebeti ön planda tutularak, âşık bir alışveriş yapmakta, canını verip, sevgilinin misk gibi kokan zülfünü almaktadır.

\section{Gözüñe cān virüp zülfüñi aldum}

Ki misk erzān olur Tatar elinden (Necâtî, G. 381/3, s. 376)

Diğer taraftan koku kavramının bulunduğu yerlerde Yemen de zikredilir. Bunun sebeplerinden en önemlisi, bir buhur maddesi olarak kullanılan ve ûd (öd) denilen güzel kokulu maddenin bu ülke ile anılagelmiş olmasıdır. Aşağıdaki beyitte, Yemen tarafından esen rüzgârın kokusunun etkileyiciliği anlatılır.

Nefesinden kohu almah dileseñ Rạmmānuñ

Zülfüni ḳohula kim rịh-i Yemendür ḳohusı (Ahmedî, G. 658/2, s. 581)

Saçın benzetildiği yerlerden biri de Hindistan'dır. Misk kokulu zülüf Hindistan, güzel kokulu yanak da Rum ülkesi olur.

Zülf-i müşgini gör ol cārı̇̇-ı kāfür üzre

20 "Kan yutturmak, çok eza, cefa etmek, pek çok ıstırap çektirmek" anlamına gelmektedir (Tanyeri, 1999: 162). 
Düşmiş ol resme mucārı̇ nite kim Hind ile Rūm (Şeyhî, G. 132/2, s. 128)

Zülüf, misk kokulu bir heykele benzetilmiştir.

Cacd-1 zülfüñ kim aṣılmış sen dil-ārām üstine

Müşg heykel dakdı bir serv-i gül-endām üstine (Ahmed Paşa, G. 277/1, s. 302)

Aşağıdaki beyitte sevgilinin zülfü ya cennet bağında misk kokan bir başak ya da amberden bir kılıç kayışı olur.

Nigārā bā $\dot{g}-1$ cennetde yā miskīn hūşsedür zülfüin

Yā canberden ḥamāyildür gümüşs serv-i ḩırāmāna (Ahmed Paşa, G. 264/3, s. 294)

Sevgilinin yanağı bostan ve zülfü de bu bostanda iki kanadından biri misk, diğeri de amber kokan bir tavus kuşu olur.

Bostān-1 ruhuñnda nice tāvūs olur ol zülf

Kim müşg ile canberden iki bāl ü peri var(Ahmed Paşa, G. 84/6, s. 178)

Sevgilinin çene çukuru Hz. Yûsuf'un kuyusu olur ve âşık buradan sevgilinin misk kokulu zincire benzeyen saçı ile kurtulmak ister.

Çāh-1 zenehdāndan çeküb ḳurtarmag̀a cān Yūsufin

Ol halka halka aṣılan zencīr-i müşsg-efşān șun (Ahmed Paşa, G. 223/3, s. 265)

Sevgilinin zülfü nala, yanağı da ateşe benzetilir ve nalın ateşe atılarak büyü yapılması hadisesi ${ }^{21}$ hatırlatılır.

Halka-i zülfini ruhsārına șaldugì bu kim

Naવ-i miskīndür anı siḥr içün āzerde ḳodı (Ahmed Paşa, G. 315/4, s. 327)

Aşağ1daki beyitte sevgilinin sümbüle benzeyen zülfü, misk kokulu gülsuyu saçan veya amber yüklü bir buluta benzetilmiştir.

Sünbül-i zülf-i carak-rízinden ol gün yüzünün

Gün yüzinde ebr-i müşgīn-i gül-āb-efşān yatur (Ahmed Paşa, G. 52/2, s.157)

Gün yüzinde zülf-i canber-bār-1 misk-āsā-yı dost

Ebr gibidür ki cism-i Muștafā üstindedür (Necâtî, G. 121/2, s. 219)

Zülüf, misk kokulu bir ipek olur ve bu ipekten sevgiliye elbise biçilir.

Șalın șalın ki luṭ ile müşgīn harīirden

21 "N'al der-âteş" denen bu olay şu şekilde cereyan edermiş: Bir kimseyi başka bir kimseye âşık etmek için kullanılmamış bir na'l üzerine âşık edilmek istenen kişilerin adı yazılarak na'l ateşe atılır ve bazı dualar edilirmiş. Buradaki na'l kızdıkça iki kişi arasındaki aşk hararetlenir ve bu sayede iki kişi birbirine âşı edilirmiş (Onay, 2007: 291). 
Hilcat biçübdür ol kad-i ra`nāya perçemüñ (Necâtî, G. 328/2, s. 345)

"Miskîn" kelimesi tevriyeli olarak hem çaresiz, aciz hem de misk kokulu anlamlarına gelecek şekilde kullanılmıştır. Amber ve miskin, sevgilinin zülfüne benzemeye çalışması, onlar için yüz karası bir durumdur.

Zülfüñe öykündügin canber görüb miske didi

Hay miskin yüz karasıdur bu sevdālar bize (Ahmed Paşa, G. 274/5, s. 300)

Âşığın gönlü, sevgilinin zülfünün kokusu dolayısıyla misk gibi kokmakta/miskin gibi olmaktadır.

Çü zülfí sāyesin mesken idindüñ̃ ey dil-i miskin

Șaḳın devr-i kamerdurur gözinüñ mekr ü ālinden (Ahmed Paşa, G. 243/3, s. 280)

Sevgilinin saçının her bir telinde, bin tane miskin (zavallı/güzel kokulu) gönül vardır.

Bu sebebden Aḥmed'üĩ șormaz șinuk göñlüni kim

Zülfinüñ her bir ḳllında biñ dil-i miskinni var (Ahmed Paşa, G. 53/7, s. 157)

Aşağıdaki beyitte de şair, âşı̆̆ın ömrünü zülüf kokusu için yele verdiğini, yani feda ettiğini söylerken "bûy" kelimesini tevriyeli olarak kullanmıştır.

Vardı cömrüm ārzū-yı būy-i zülfü̈ñden yile

Ol ḳuru sevdāda hạṣıl çünki būdur ne eylesün (Ahmed Paşa, G. 244/7, s. 281)

Nasıl taze ve güzel kokan misk, ipekler içinde saklanıyorsa, sevgilinin süslü başlığı içinde de zülfü o şekilde saklanmaktadır.

Zülf-i siyehüñ çıłmadı zībā külehüñden

Zïrā ki harîr içre olur misk-i ter ey dost (Ahmed Paşa, G. 16/4, s. 131)

\section{Su/Gözyaş1}

Şair, sevgilinin eşiğine misk kokulu gözyaşı akıtmayı, zamanı dolu ve yararlı geçirmekle eş değerde tutar.

Sözi ile hoşs-dem itmege Aḥmed zemāneyi

Aḳtdı işigüñe yine müşsg-bār āb (Ahmed Paşa, K. 37/52, s. 105)

\section{1. Şarap}

Şarap ile koku arasındaki münasebet genellikle misk ve kırmızı renk etrafında şekillenir. Sevgilinin elindeki şarabın kokusu ûd (öd) ağaci22 gibi güzel kokar ve rengi de kırmızı boya ağacı gibidir.

İ̧ ol servüñ elinden bir ḳadeh kim

22 Hindistan'dan gelen bir cins kıymetli odun ki yakıldıkta bir râyiha-i tayyibe vermekle odalarda mahsûs micmerlerde yanar, öd ağacı (Kâmûs-ı Türkî, 1317: 955). 
Kọ̣usı 'ūd ola rengi beḳāmdur (Ahmed-i Dâ'î, G. 167/6, s. 169)

Ceylanın karnında biriken kan (misk) ile âşıkların yüreğinin kan dolması arasında ilişki kurulur. Aşağıdaki beyitte şair, kendisini mecliste dönen bir şişeye benzeterek yüreğinin kan (misk) dolduğunu söyler.

Meclisde şişseler gibi miskin Necātìn nüñ

Kan toldurub yüregini boynını burdılar (Necâtî, G. 57/5, s. 180)

\section{Toprak}

Toprak daha çok, sevgilinin bulunduğu yer ve ölüm teması münasebetiyle kullanılır. Bu münasebette rüzgâr özellikle, sevgilinin kokusunu âşığa taşımakla maruftur. Toprağın altında veya üstünde, sevgilinin kokusunu alanlar tekrar hayat bulur. Ölen âşığın toprağı etrafa muhabbet kokusu saçar (Tolasa, 2001: 444).

Sevgilinin gölgesi bile toprağı/zemini misk gibi yapar.

Șal hāke sāyeñi kim ola müsgg-bū zemin

Șaç suya cür ${ }^{c} a \tilde{n} ı$ kim ola şehd-bār āb (Ahmed Paşa, K. 37/12, s. 103)

Bahar rüzgârı, sevgilinin ayak toprağının misk kokusunu her yere yayarak baharı canlandırmaktadır.

Hūk-i pāyuñ müşgini götürmese bād-ı bahār

Nev-'arūsān-ı çemen ummazdı andan nükheti (Ahmed Paşa, G. 350, s. 351)

Sevgilinin kokusunu taşıyan sabah rüzgârı, yine sevgilinin yolunda toprak olmuş olan âşığa can verir.

Ben ḳara toprag̀ idüm cān virdi būyuñdan șabā

Hey ne cān-perver ḳyāmet dil-rübāsın bilmedüm (Ahmed Paşa, G. 191/2, s. 245)

\section{Yaradılış}

Divan şiirinde daha çok "hisâl" ve "hulk" kavramları ile anlatılan sevgilinin yaradılışı sayesinde dünya misk gibi kokar. Seher yelinin taşıyıp yaydığı hoş kokuların kaynağı sevgilinin saçı, beni ve sevgilinin yaradılışıdır (Güfta, 2010: 123). Aşağıdaki beyitler, bu hayale örnek teşkil edebilir.

Dünya sarayı, sevgilinin yaradılışı ile misk gibi kokar.

'Ulyā serīiri oldı vișālüñ̃le pür-sürūr

Dünyā sarāyı oldı hișālüñle müsşg-bār (Ahmed Paşa, K. 42/8, s. 116)

Sevgilinin yaradılışı, sabah rüzgârını güzel kokular satan bir attar yapar.

Ey ki hulkuña șabā catțār-1 bāzār-1 seḥer

Vey ki luṭuñla cihān mānend-i gülzār-1 cinān (Mesîhî, K. 5/15, s. 32) 
Sevgilinin güzel kokulu yaradılışına amber bile kul olur.

Kul oldı hulkuña cānıla anber

Olalı sỉretüñüñ müşgi fāyị̣ (Ahmedî, K. XVI/8, s. 46)

İlkbahar rüzgârı, sevgilinin yaradılışından kokladığı için bu kadar güzel kokmaktadır.

Şehā hulkuñ nesīminden dimāğg-ı cān mucatțardur

Meger bir şemmedür gūyā nesīm-i nev-bahār andan (Ahmed-i Dâ'̂̂, 9/11, s. 23)

\section{Yüz/Yanak}

Sevgilinin yüzü gül bahçesine benzer. Bu gül bahçesinin kokusu, sabah rüzgârı marifetiyle âşığa ulaşır ve bu koku tevriyeli bir kullanımla Necâtî’yi "miskîn" eder.

Diyesin derd ile iñlerdi Necăti miskin

Ey șabā sorar ise ol yüzi gül-zār beni (Necâtî, G. 633/6, s. 545)

Sevgilinin yană̆ı, reyhan ve susam çiçeği gibi kokar.

Ol büt-i simm-tenüñ serv-i semendür kokust

‘Ārtż̇ı sūsen ü reyḥān-ı çemendür ḳoḳusı (Ahmed-i Dâ'î, G. 180/1, s. 177)

\section{Kokunun Soyut Niteliklerle Birlikte Kullanımı}

Koku kavramı, cömertlik, acı, vefa, lütuf vb. soyut nitelikleri ifade etmek için de kullanılır. Bu durumda koku daha çok, ilgili soyut kavramın tesir derecesini belirlemek gibi bir görev üstlenir.

Zamanın bağında vefanın kokusu kalmamıştır.

Reng-i cizārı zerd olub ol lāle-çihrenüñ

Bāg̀-ı zemānda kalmadı būy-i vefā dirìg (Ahmed Paşa, K. 45/7, s. 119)

İyilik edenlerin iyiliklerinin "hoş kokuları", sonsuza kadar kalıcılığını korur.

Bāğ-1 sacādet isteyen eylük ide k'eyülerüñ

Hoş kohusı ebed kalur gül bigi kim gül-āb olur (Şeyhî, G. 24/4, s. 78)

Güle benzeyen dünyada, başa gelen dertler, rahatlığın kokusunu ortadan kaldırır.

Gül-i dünyāda yoḳdur būy-i rāhat

Hemān ‘Avní irişürr derd-i serler (Avnî, G. 15/7, s. 7)

Sevgilinin lütfunun güzel kokusu o kadar geniştir ki bütün cihanı 1tır ve amber ile doldurur.

Şemme-i luṭuñla gālib hem-nefes oldı cihān 
Kim tolar dehrüñ dimāğg her gice ‘ṭr u aabīir (Mesîhî, K. 11/17, s. 52)

Âşık, güle benzeyen sevgilinin sağlığına elem kokusunun yani hastalığın uğramamasını temenni eder.

Görmeye devletüñ güneşi zerrece zevāl

İrmeye șḷhhatüñ güline şemme-i elem (Şeyhî, K. 10/36, s. 34)

Saç, âşık için ulaşılması gereken kutsal ve vatan sevgisi kokan bir yerdir.

Zülfüiñe irmegiçün itdi göñül cānı revān

N’eylesün çünki anuñ ḥubb-ı vațandur ḳohusı (Ahmedî, G. 658/6, s. 582)

Sevgilinin cömertliğinin kokusu o kadar tesirlidir ki, sabah rüzgârı bu kokudan biraz nasiplense, dikenleri ve çer çöpü gül yapar, gülsuyunu da suya kandırır.

Bād-1 șabāya şemmesi feyz olsa cūduñuñ

Hār u hası gül eyleye sìr-āb ola gül-āb (Şeyhî, K. 12/24, s. 37)

Aşağıdaki beyitte maşuğun sevgiliye duyduğu muhabbet "itır" ile anlatılmıştır. Âşığın sinesi bir tütsüdür. Gönül ve can da bu tütsüde yanan bir üzerliktir. ${ }^{23}$ Buradan etrafa yayılan koku da sevgiliye duyulan "muhabbet kokusu"dur.

Micmer-i sīnede kim yandı sipend-i dil ü cān

Bir perỉ dac vetine 'Tṭr-1 mahabbetdür bữ ${ }^{24}$ (Mesîhî, G. 198/6, s. 245)

Sevgilinin adaletinin güzel kokan rüzgârı gül bahçesinde esseydi, sabah rüzgârı sevgilinin kokusu olmadan hiç birşey ifade etmeyeceğini anlardı.

Eger cadlüñ nesīminden ḳoḳu irse gülistāna

Șabā güstāhlık kıllmaz gül ü nesrīn-i zỉbāya (Ahmed-i Dâ'î, G. 21/17, s. 60)

Âşığın gizlemeye çalıştı̆̆ı aşkın misk kokusu gizli kalmaz.

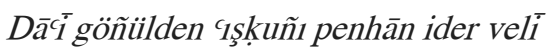

Müşküñ koḳusı sırr ile penhān olur mı hị̧ (Ahmed-i Dâ'î, G. 107/7, s. 130)

Sevgilinin saçının kokusunun kudreti aşk kavramını güçlendirir.

Eser-i şām u seḥer yog̀ idi dünyāda dahi

IŞsı müssg ider idük țurra-i țarrāruñ ile (Necâtî, G. 552/6, s. 489)

23 Koku verme özelliğinin yanında sipend (üzerlik) hakkında Ahmed Talat Onay şu bilgiyi vermektedir: “Üzerlik tohumu ki "tütsülük" de derler. Ateşe atılınca çtırtı yapar. Nazar değmemesi istenilen veya nazar değdiği sanılan çocuk veya kimsenin üzerinde -içinde ateş bulunan- bir kap gezdirerek üzerlik yakarlar. Ocak veya mangalda yakarak tüttürürler. Tohumlar çıtırdadıkça musallat olan cinler dağılırmış" (Onay, 2007: 352).

24 Alıntıladığımız metinde " $b u$ " şeklinde geçen kelimeyi, beytin anlamı çerçevesinde koku anlamındaki " $b \vec{u}$ ” şeklinin de şair tarafından düşünülmüş olduğu kanaatine vardığımız için yukarıdaki şekilde yazdık. 
Sevgilinin zülfü hile ve fitne kokar.

Çeşm-i gammāzına bak ġamz u hịeldür bakıısı

Zülf-i mekkārını gör mekr ü fitendür koḳusı (Ahmed-i Dâ'î, G. 180/4, s. 178)

Şairler, gücünü ve tesirini ifade etmek için şiirlerini güzel bir kokuya benzetebilirler. Aşağıdaki beyitte de şair, şiirinin kudretini ıtır dükkânında satılan ambere benzetir.

Siicr isteyen Necātí'ye gelsün ki vechi yok

'Anber șatun alan kişi catțāra gelmeye (Necâtî, G. 503/7, s. 455)

\section{SONUÇ}

Şair, sevgilinin üstünlüğünü, en basit ifadesiyle "sevgili güzeldir" olarak kısa bir şekilde vermek yerine, Divan şiiri dünyasının kendisine tanıdığı imkanlardan istifade etmenin yanında çeşitli sanatları ve mazmunları da kullanarak sevgiliyi benzetme ve hayal dünyasında çok farklı ve yoğun bir ifade ile anlatır. Bunun sonucunda, tefekkür ve kültür harekete geçerek şair, zaman üstülügü ve özgünlüğü yakalamış olur. Divan şairlerinin, tabiat unsurlarının kullanımındaki başarısı, bu özgünlüğün bir ifadesi olabilir. İşte burada, "koku" kavramının çok değişik ve orijinal hayallerle ortaya konmuş olduğunu görebiliriz.

Görüldüğü üzere "koku" kavramı Divan şairlerinin dilinde birçok şekilde yer almaktadır. Renk, rüzgâr, cevher, şehir ve ülkeler, huy ve yaradılış, uzuvlar, eşyalar ve tavır, su, deniz, yazı çeşitleri, mevsimler, soyut nitelikler, toprak, şiir, bahar, micmer vb. kavramlar, bilhassa tevriye, teşbih, istiâre, mübâlağa ve hüsn-i ta'lîl gibi sanatlar yardımıyla, sevgiliyi koku ekseninde övmek için kullanılmıştır. Tabii bunlar sadece XIV ve XV. yüzyıllardaki divanların taranmasıyla ortaya konmaya çalışılmıştır. Diğer yüzyılda kaleme alınan divanların da incelenmesiyle Divan şiirindeki "koku" kavramının daha zengin bir anlam dünyasına sahip olduğu görülecektir.

\section{SUMMARY}

Divan poets reflected almost all aspects of nature in their poems. Sometimes a sultan, sometimes state or religion, sometimes a imaginary dear to come as the face of the memduh, the "sultan" of a whole being considered. He is at the service of the natural poet as an expression of being close to him. Any kind of concrete, abstract or concrete, is a tool in which there are various elements of art on the way to love. These tools both provide an opportunity for the love of the lover to reveal the love of the poet and the poet's power of art. One of these tools is the smell concept. Because the smell is the main source of human beings and all living things, its position in nature has been determined most viciously by their pen due to the observing ability of the Divan poets. Therefore, it can be said that the Divan poet, who created the table in unlimited depths (verse form, rhythm, rhyme, etc.) in a limited form, has a culture bearer identity. The fragrance, one of the indispensable elements of nature, is dealt with by the poets, especially the relation of the beloved with the lover. XIV and XV. According to the data we obtained from the century clerics, the Divan poets of this century have written their poems especially in terms of the points we tried to rank in three headings above, by using personalization, beautiful simile and exaggeration arts. Odor poets, color (especially black color), wind, ore, cities and countries, nature of man, beloved limbs, things, attitude, water, sea, types of writing, seasons, abstract qualities (fidelity), generosity, pain, grace etc.), soil, spring, micmer (incense container) and so on. by associating with many simile and imaginary world 
have revealed.

The fragrance, in addition to being similar to various beings, especially nature elements, has the characteristics of healing and giving life, making love to itself and having life meaning. When we examine the analogy and imagination in the divans around the concept of fragrance in the centuries in question, we can say that the words that can meet this concept are grouped into three groups. Musk, reyahin, amber, abir, itr (atr), nafah, such as himself a fragrant substance; bûyâ, tîb, such as fragrance of any good smell, used as adjectives and râyiha, bûy, nekhet, schemim, shamm (shamme) and fâyiha in the definition of "fragrance" or "fragrance". In this analogy and imagination, the concept of fragrance emerges in a wide variety of ways: Odor is handled, even superior, with China, Hita (Hoten). Musk fragrant line (quince feathers, beauty), the book-like cemalarine commentary. The threshold of the door of your lover smells of musk. Misk leaves the place of hair to shame. The fragrant quince feathers, ie the line of lover, are generally associated with the Gubar and the Reyhânî script. Beloved, because of the foot of the foot spread out the dust / soil of Chinese musk is not available. In the morning the wind ornaments the garden of the beloved with the scent of your hair. Your hair is sometimes a scallop spike. Hita (Hoten) stings the blood, the lover's hair remains in the face of the blood. Hair is a chain of musk-scented chains, and it hangs the hearts of the lover.

In the morning wind solves the hyacinth-like hair of her beloved, so the breath of love comes to her breath.

The mind of all kinds of wealth, thanks to the world's most beautiful scents of dollars. The sweet tongue of your beloved, as well as the fragrance of the sweet smell of the scent of every problem. The beautiful scent of black hair is not even found in the belly of the Chinese. Hence the beautiful fragrance, like hair, impresses impressive. The hair becomes sticks of musk, played in the javelin. Hita cannot compete with the morning wind because it carries the smell of your girlfriend. Eyebrow becomes a canopy that smells like a beautiful scent. Her beloved seed on her fragrant face becomes a solemn black love seed. Quince feathers, blackness and fragrance of the fragrance are used in conjunction with the appearance of fragrance.

The most commonly referred to as "amber and musk". The poet, instead of giving the love of the beloved in a short way, uses the various arts and idioms in addition to benefiting from the opportunities that the world of Divan poetry gives him, he likens the lovers and tells the world of imagination with a very different and intense expression. As a result, contemplation and culture take action, and the poet seizes time mastery and originality. The success of Divan poets in the use of natural elements can be an expression of this specificity. Here, we can see that the concept of $\mathrm{u}$ odor $\mathrm{in}$ is revealed with very different and original dreams. As can be seen, the concept of de odor "takes place in the language of Divan poets in many ways. Color, wind, ore, cities and countries, habit and creation, limbs, goods and attitude, water, sea, types of writing, seasons, abstract attributes, earth, poetry, spring, micmer and so on. concepts, especially binary narration, analogy, exaggeration and beautiful analogy with the help of arts, used to praise the sweetheart on the axis of fragrance. Of course, these are only XIV and XV. It was tried to be revealed by the screening of divans in the centuries. With the study of the divans written in the other century, it will be seen that the concept of "smell daha in Divan poetry has a richer world of meaning. The relationship of the lip to the fragrance is usually related to the alfalfa. The eyebrow-odor relationship is especially handled in black. Therefore, eyebrows are often referred to as musk. The morning wind, which is one of the most frequently used wind types in Divan poetry, is dealt with in the context of carrying, distributing and spreading more. Morning wind, because of the fragrance of your lover's hair is fond. The concept of fragrance is 
the most commonly used hair. Therefore, the simile and the center of the imagination are based on hair and fragrance are some of the world: The hair is the trap of the fragrance, and I am the musk. The curves of the hair of the beloved, double-hearted lips. The hair becomes a smoker with musk scent. 


\section{KAYNAKÇA}

Aça, Mehmet vd. (2011), Başlangıçtan Günümüze Türk Edebiyatında Tür ve Şekil Bilgisi, İstanbul: Kesit Yayınları.

Ahmed-i Dâ'ı̂ Divanı, Metin-Gramer-Tıpkı Basım (2001), C I, (haz. Mehmet Özmen), Ankara: TDK Yayınları.

Ahmedî Dîvân, (haz. Yaşar Akdoğan), T.C. Kültür ve Turizm Bakanlığı Kütüphaneler ve Yayımlar Genel Müdürlüğü, ISBN: 978-975-17-3344-3, e-kitap.

Ahmed Paşa Divanı (1966), (haz. Ali Nihad Tarlan), İstanbul: Millî Eğitim Basımevi.

Ahterî-i Kebir (2009), Ahterî Mustafa Efendi, (haz. Ahmet Kırkkılıç, Yusuf Sancak), Ankara: TDK Yayınları.

Arıkoğlu, İsmail (2008), “Divan Şiirinde Şehir Adlarının Tevriyeli Kullanımı Aydın-Tire Örneği", Selçuk Üniversitesi Türkiyat Araştırmaları Dergisi, S 23, s. 137-144.

Avnî (Fatih) Dîvânı, (haz. Muhammed Nur Doğan), T.C. Kültür ve Turizm Bakanlı̆̆ 1 Kütüphaneler ve Yayımlar Genel Müdürlügü, ISBN: 978-975-17-3348-1, e-kitap.

Batislam, H. Dilek (2005), "Divan Şiirinde Sabâ" Osmanlı Araştırmaları, XXVI, Prof. Dr. Mehmet ÇAVUŞOĞLU'na Armağan II, İstanbul, s. 95-117.

Burhân-ı Katı (2000), Mütercim Âsım Efendi, (haz. Mürsel Öztürk, Derya Örs), Ankara: TDK Yayınları.

Cem Sultan'ın Türkçe Divanı (2013), (haz. İ. Halil Ersoylu), Ankara: TDK Yayınları.

Demir, Muhammet Ali (2015), Divan Şiirinde Sevgilinin Saçının Kokusu, İstanbul: Boğaziçi Üniversitesi.

Devellioğlu, Ferit (1990), Osmanlıca-Türkçe Lûgat, Ankara: Aydın Kitabevi.

Erdoğan, Mehtap (2013), Güzellik Unsurlarıla Divan Şiirinde Sevgili, İstanbul: Kitabevi Yayınları.

Güftâ, Hüseyin (2010), “Divan Şiirinde Vakt-i Seher", Uluslararası Sosyal Araştırmalar Dergisi, Klâsik Türk Edebiyatının Kaynakları Özel Sayısı, Prof. Dr. Turgut KARABEY Armağanı, C 3, S 15, s. 93-137.

Kâmûs-ı Türkî (1317/1899-1900), Sâmî Şemseddin, İkdâm Matba'ası, Dersaâdet.

Kaplan, Yunus-Poyraz, Yakup (2010), “Divan Şiirine Kaynaklık Etmesi Bakımından Oyunlar" Uluslararası Sosyal Araştırmalar Dergisi, Klâsik Türk Edebiyatının Kaynakları Özel Sayısı, Prof. Dr. Turgut KARABEY Armă̆anı, C 3, S 15, s. 151-175.

Lehcetü'l-Lügat (1999), Şeyhülislam Mehmed Esad Efendi, (haz. Ahmet Kırkkılıç), Ankara: TDK Yayınları.

Lügat-i Ni'metu'llâh (2015), Ni'metu'llâh Ahmed, (haz. Adnan İnce), Ankara: TDK Yayınları.

Mesîĥ̂ Dîvânı (1995), (haz. Mine Mengi), Ankara: Atatürk Kültür, Dil ve Tarih Yüksek Kurumu, Atatürk Kültür Merkezi Yayınları.

Mükemmel Osmanlı Lügati (2009), Ali Nazîmâ-Fâik Reşad, (haz. Necat Birinci, Kâzım Yetiş, Fatih Andı, Erol Ülgen, Nuri Sağlam, Ali Şükrü Çorok), Ankara: TDK Yayınları.

Necatî Beg Divanı (1963), (haz. Ali Nihat Tarlan), İstanbul: Millî Eğitim Basımevi.

Onay, Ahmet Talât (2007), Açıklamalı Divan Şiiri Sözlü̆̆̈̈, (haz. Cemal Kurnaz), Ankara: Birleşik Yayınevi.

Öztoprak, Nihat (2004), Saç Kitabı, ed. Emine Gürsoy Naskali, “Divan Şiirinde Güzelin Saç Kokusu", s. 315-334, Kitabevi Yayınları.

Pala, İskender (2010), Ansiklopedik Divân Şiiri Sözlüğü, İstanbul: Kapı Yayınları.

Resimli Türkçe Kamus (2004), Raif Necdet Kestelli, (haz. Recep Toparlı, Belgin Tezcan Aksu, Canan Selvi Kanoğlu, Seyfullah Türkmen), Ankara: TDK Yayınları. 
Şeyĥ̂ Dîvân, (haz. Halit Biltekin), T.C. Kültür ve Turizm Bakanlığ1 Kütüphaneler ve Yayımlar Genel Müdürlügü, ISBN: 978-975-17-4078-6, e-kitap.

Tanyeri, M. Ali (1999), Örnekleriyle Divan Şiirinde Deyimler, Ankara: Akçağ Yayınları.

Tolasa, Harun (2001), Ahmet Paşa'nın Şiir Dünyası, Ankara: Akçă̆ Yayınları.

Yeniterzi, Emine (2010), "Klasik Türk Şiirinde Ülke ve Şehirlerin Meşhur Özellikleri", Uluslararası Sosyal Araştırmalar Dergisi, Klâsik Türk Edebiyatının Kaynakları Özel Sayısı, Prof. Dr. Turgut KARABEY Armağanı, C 3, S 15, s. 301-334. 